\title{
Canted Desire
}

\section{Otaku Performance in Japanese Popular Culture}

\section{YUJI SONE}

MACQUARIE UNIVERSITY

\section{-INTRODUCTION}

The term otaku attracts much attention in discussions about Japanese popular culture, consumerism and technoculture. It is a complex and elusive term that addresses varied practices and fandom-related activities. The targets of otaku fans' interests can include manga, anime, games, the internet, computers, books, figurines, celebrities, special effects, and cosplay (costume play). ${ }^{1}$ While 'otaku' is roughly equivalent to the term 'nerd' in English and it usually refers to men, it can also be used for both sexes (although I won't be discussing female otaku here). ${ }^{2}$ The stereotype of the male otaku is that of an introvert, but otaku who frequent game arcades, on the other hand, are thought to be extroverts. ${ }^{3}$ While the otaku is typically regarded negatively because of his presumed antisocial attitudes, ${ }^{4}$ otaku fandom activities can also facilitate a collective social bond amongst members of a particular otaku subculture. 5

Otaku culture is now regarded as a grassroots element of Japanese 'soft power', used in global strategies to promote Japan in the twenty-first century. ${ }^{6}$ Cultural ISSN 1837-8692

Cultural Studies Review 2014. @ 2014 Yuji Sone. This is an Open Access article distributed under the terms of the Creative Commons Attribution 4.0 Unported (CC BY 4.0) License (https://creativecommons.org/licenses/by/4.0/), allowing third parties to copy and redistribute the material in any medium or format and to remix, transform, and build upon the material for any purpose, even commercially, provided the original work is properly cited and states its license. Citation: Cultural Studies Review (CSR) 2014, 20, 3700, http://dx.doi.org/10.5130/csr.v20i2.3700 
anthropologist Mizuko Ito states that otaku culture has been exported overseas, and is now 'situated at a transnational confluence of social, cultural, and technological trends'. ${ }^{7}$ Yet, in Japanese sociologist Shinji Miyadai's view, the West's interest in otaku culture is mainly concerned with manga and anime products, which would not provide a full picture of otaku culture. ${ }^{8}$ Unfortunately, the view of the otaku as a techno-geek is still prevalent in journalistic writing in the United States of America and in Australia, perpetuating the familiar rhetoric of 'techno-orientalism', which focuses upon the strangeness and exotic nature of the 'other'. 9 The otherness of otaku culture is often represented in terms of the most controversial aspect of Japanese male otaku practice, which is to do with sexual fantasies about cartoon images of young girl characters. Male otaku are known to admire cartoon images of young girl characters, whether two-dimensional or three-dimensional, particularly in the context of fan subcultures, and can develop strong psychosexual bonds with these characters. How can this practice be examined without sensationalising it?

Western academics have examined the male otaku's carnal attachments in terms of Japanese relations between humans and contemporary technological artefacts. This is because the otaku's engagement with particular images can be viewed as a culturally specific instance of an engagement with what anthropologist of science and technology Lucy Suchman calls 'sociomaterial entities'.10 The male otaku's phantasmic practice needs to be conceived as a complex entanglement of technology, society and culture. In this sense, it is useful to look at the correlation between Japanese animism and technoculture. For example, Anne Allison coined the term 'techno-animism' to discuss the consumption of commodities, particularly toys, through the themes of an 'animist unconscious' ingrained in the Japanese psyche and the more generalised and widely recognised high regard for advanced technology in Japan. ${ }^{11}$ The figure of the otaku has been mentioned in relation to 'the national obsession with techno-constructed realities'.12 Taking their cue from Allison, critical theorist Casper Bruun Jensen and sociologist Anders Blok discuss an animism that is applied to technological artefacts in Shintoism in terms of the Latourian view of symmetries between nature and culture.13 $0 \mathrm{n}$ the other hand, Patrick Galbraith, a researcher on otaku culture, discusses bishōjo (pretty girl) games-dating simulation games with varying levels of explicit material. ${ }^{14}$ Galbraith sees possibilities for new relations between technology, self and the world in the 
otaku's intimate and invested interaction with young female animation figures. While Galbraith's use of Western theoretical concepts, instead of animism, such as 'techno-intimacy' (Allison), 'affect' (Massumi), or 'companion species' (Haraway), is relevant, these terms alone are inadequate to explain the otaku's engagement with cartoon images.

Rather than turning to the catch-all frame of animism or deferring to Western theoretical concepts in this article, I consider how Japanese traditions of somatic and material conditioning relate to and assist in explaining the otaku's carnal affections for such images. To that end, I will discuss the embodied sense of the Japanese self in the world and embodied relations to signs, using iconic terms such as 'ki' and 'mi'. These traditional concepts help clarify the Japanese engagement with nonhuman artefacts, even those attachments that appear questionable, aberrant or unreal. I revisit these familiar terms not to reignite a discourse of Nihonjinron (essentialist discussions about Japanese uniqueness) against Western traditions, but to remind us that traditional forms of embodied thought persist even in the age of the internet. Japanese 'traditional' thinking shapes Japanese perceptions in subtle yet pervasive ways, as is evident in everyday phrases and concepts. This accepted cultural knowledge and customary thinking significantly informs relations between humans, their environment and objects in Japan. Male otaku practice is an oblique and elaborated manifestation of the above traditions in contemporary Japanese culture, which functions through a particular language of social gestures, postures and attitudes.

Male otaku practice reflects the importance of social performance in Japan. In contrast to an understanding of 'performance' as false, insubstantial and limited to appearance (that is, as opposed to truth, authenticity, and the real) I propose performance as a profound process for making social meaning in Japan. Japanese social interaction requires dual roles of people-they are asked to be an actor at one time and an audience at another. Otaku behaviour complexly contains extra layers of message, that is to say communicable meaning, to those contained in ordinary social performance in Japan. In other words, otaku practice is nested within pre-existing Japanese social conventions of performance, which are already highly culturally specific. Importantly, the performativity of otaku practice needs to be understood differently from gender performativity per Judith Butler, which seeks to subvert.15 
The performativity of otaku practice works inwardly, through irony and selfreflexivity. Aspects of detachment, theatricality and distancing are part of otaku practice. In the sense that it is coded language that is meaningful to those within its own subcultural community, the otaku's self-reflexive posture can seem like acts and attitudes that are often described as 'camp' in the West. I use the notion of camp in comparative terms to discuss how the otaku 'performs' for other otaku through codes.

Making such a comparison requires some explanation. Camp is another complex term, and theorists are not in clear agreement when defining it. Moe Meyer, for example, criticises Susan Sontag's 'Notes on Camp' (1964), as an apolitical aestheticism of a taste for the vulgar and the kitsch, which avoids a deeper analysis of the relation between 'Camp taste and homosexuality'.16 Fabio Cleto, on the other hand, critiques Meyer for essentialising critical and political 'Camp', with a capital ' $\mathrm{C}$ ', as the original, and male homosexual, meaning of the term, as opposed to a spurious 'camp' in lower case. ${ }^{17}$ Camp has wider meanings. For Cleto, 'camp and queer are cognate terms: camp is queer as a mode of being', referring to thoseincluding both homosexual and heterosexual men and women-who resist categorisation from a single perspective. ${ }^{18}$ Similarly, following Ross Chambers's view of camp as a 'performance genre' of collective interaction, David Halperin states that camp can be 'an appropriate vehicle for expressing various sorts of cultural and political dissidence beyond the merely (homo)sexual'.19 My use of the term 'camp' in this discussion follows Chambers's and Halperin's: I consider camp as a mechanism that is not unlike the otaku's self-reflexive 'performative' behavior.

Providing a similarly inclusive view of the concept of queer, Japanese literary studies scholar Keith Vincent discusses 'otaku perversion'.20 Referring to queer theorists such as Eve Kosofsky Sedgwick, Judith Butler and Michael Moon, Vincent examines the male otaku's 'perversion' as queer within the Japanese context, highlighting its denial of distinctions between sexual fantasy and reality; its separation of sexual desire, social identities and natural bodies; and its implicit stance against the heterosexual normativity of sexual relations with real bodies. ${ }^{21} \mathrm{In}$ contrast to the narrower use of 'queer' as a political term in discussions on LGBT issues in Japan, Vincent's use of the term is, in fact, akin to hentai, a Japanese word often used when translating 'queer'.22 With derogatory and pejorative connotations, 
hentai signifies a wide range of sexually 'deviant', 'perverse' and 'abnormal' practices, as seen from the perspective of mainstream, heterosexual normalcy in Japan. ${ }^{23}$ Importantly, unlike the term 'queer' in English, hentai does not connote practices with a critical edge in terms of gender and sexual politics; that is, it is not subversive in Butler's sense.

I will now develop these points through textual and interpretive analysis from an interdisciplinary perspective. First, I will discuss the notion of intersubjectivity in traditional Japanese thought before examining its contemporary manifestation in male otaku practice.

\section{-'SENSING' AND 'SENSED' IN JAPAN}

Central to an understanding of human-nonhuman relations in Japan is the question of how the Japanese articulate a sense of the self-formulated in relation to the surrounding environment, which must also include non-organic objects. The sociocultural matrix of contemporary Japan might be described in terms of layers of influences, including the traditions of Shintoism and Buddhism, as well as those derived from Chinese culture. Japanese myth and traditional animism encourage a relationship with nonhumans such as animals or plants, and even non-organic objects such as rocks, by anthropomorphising them. Japanese anthropomorphism is a reflexive mechanism where the observation of animal behavior reflects back upon the human observer, an approach detailed in traditional myths. ${ }^{24}$

The sociological notion of 'the sensuous self' helps to clarify this anthropomorphic and reflexive sense of the self in Japan. Sociologists Phillip Vannini, Dennis Waskul and Simon Gottschalk discuss the notion of 'the sensuous self' as an application of George Herbert Mead's social behaviourism. ${ }^{25}$ According to Herbert Blumer, Mead argued that human conduct can be influenced by 'memories of earlier experiences' or 'images of other people and groups', information that is not perceivable 'in the immediate situation'.26 Mead's social behaviourism understands an expanded 'field of action' where human acts take place beyond the organic and biological spheres, the established domain of scientific behaviourism. ${ }^{27}$ The notion of 'the sensuous self' by Vannini et al. extends Mead's idea of the 'field' by focusing on somatic sensations in the formation of the self. ${ }^{28}$ Adding 'somatic perception of the world' to other factors involved in the conception of the self, Vannini et al. state 
that the self is both 'sensing' and 'sensed' by itself and others, in accord with Mead's idea of the self as 'emergent in the dual processes of knower and known'. ${ }^{29}$ The dual operation of 'sensing' and 'sensed' is regulated through 'somatic rituals' that are 'habits of sensing and sense-making'. ${ }^{30}$ The former means 'a learned sense making pattern' and the latter is understood as an individual or a collective expression of the agreed norms of sensory performance. ${ }^{31}$ 'The sensuous self' emerges in the link between these two types of ritual, one that is a making-sense of one's sensing, and the other that is the incorporation of this making-sense into an existing semiotic field.

While these concepts were first articulated in relation to Western cultures, this notion of sensing and sense-making is applicable to the Japanese situation. The concept of ' $k i$ ' underlies the somatic expression of Japanese cultural exchange. The Japanese term ki originates from the Chinese word qi (also ch'i), often translated in English as energy or life force. In acupuncture and Chinese medicine, $k i$-energy is believed to circulate throughout the non-anatomical living body that is mapped by a system of meridians. The everyday usage of the term in Japanese, however, extends beyond its original meaning in Chinese. A large number of common idioms and set phrases use the term, describing communicative attitudes and expressions for emotion, temperament, consciousness or will. This term is elusive; it is not easily defined in English. As there is no corresponding English term, I will explain it with examples. Expressions of feeling or emotion, for example, include the following: $\mathrm{Ki}$ ga tatsu ( $k i$ stands upright, that is, be angry); Ogenki desu ka? (how is the state of your ki?, that is, how are you?); Kimochi ga warui (the way I hold my ki is bad, that is, I don't feel well). The word $k i$ can also be used to describe mental states. Examples include: Ki ga muku (the ki posturing itself in a desired direction, that is, to feel like); Ki ga aru (to have ki, that is, to be interested); Kio o hiku (to draw ki, that is, to attract attention); Ki o tsukeru (to put on $k i$, that is, to be careful). There are common, everyday expressions that all Japanese people, from children to the elderly, would use.

These phatic expressions of $k i$ in daily usage suggest a particular, commonly accepted somatic relation between the self and the other in Japan. Ki refers to the underlying workings of one's interior physical and psychological state. According to sociologist Hisa Kumagai, 'the "concrete" experience of jibun [the Japanese sense of 
self] through the sensation of $k i$ differentiates the self from the other'. ${ }^{32}$ At the same time, one's jibun is sensitive to the other's ki. Philosopher Yuasa Yasuo states: 'The flow of $k i$ is a passage mediating this interior and exterior.' ${ }^{33}$ Recognising the $k i$ energy of a person who is facing you suggests a cultural conception of a kind of meeting of ki-energies. Shigenori Nagatomo, a scholar of comparative philosophy and Japanese Buddhism, uses the term 'intercorporeality' to discuss 'a temporary interfusion of the $k i$-energies, confluenced together when plural lived bodies come together' ${ }^{34}$ Nagatomo, then, proposes a notion of inter-subjectivity in which 'neither the self nor the other can exist independently from each other'. 35

What needs to be highlighted is that, in the Japanese cultural view, the interaction of $k i$-energies between people is always in flux. While $k i$ is essential for human communication, $k i$ as a vital energy needs to be managed. Martial arts such as karate or aikido (literally meaning 'the way of unifying $k i$ ') teach how to cultivate, control, or take advantage of the $k i$-energy in face-to-face combat situations. A person's ki energy can be harmful to others. Hence, the flow of ki-energy is monitored in various forms of communicative exchange.

I will now discuss the culturally specific binary construction of 'passive-active', which assists in regulating a person's ki energy. Passive-active relates to the honouring of 'the other' ahead of oneself. It represents another dual operation in Japanese social relations-that of 'performing' and 'performed'-which I will relate to the male otaku's coded gesturing.

\section{-PASSIVE-ACTIVE}

While Japan has become increasingly Westernised since the nineteenth century, the proprieties of older cultural and social practices persist to the present day. Japan remains a 'high context' culture, to use Edward T. Hall's term. ${ }^{36}$ Facets of everyday public behaviour, including non-verbal expression, are to a certain extent regulated by socially accepted (traditional or modern) customs. Social behaviour is governed by codes of etiquette appropriate to a particular situation, and determined according to gender, age and social status. While contemporary Japanese may play down their expectations concerning social behaviour in everyday life, the importance of appropriate behaviour surfaces in the workplace and on ritualised occasions, such as weddings or funerals. In the Japanese context, the importance of 
shared behavioural codes that separate insiders from outsiders is evident even in internet activities such as blogging or file sharing. ${ }^{37}$ I will return to this distinction later in terms of male otaku culture. Here, the key point is that individuals participate in social rituals by performing according to accepted codes that are shared within a community.

In this regard, the core argument of Roland Barthes's well-known discussion of Japan in the late 1960s, detailed in his Empire of Signs, is still relevant today. ${ }^{38}$ Barthes examines Japan as the site of his search for an alternative to the Western symbolic system, highlighting the underlying principles of Japanese cultural phenomena including its food, the Pachinko parlour, the city of Tokyo, the wrapping of packages, Bunraku and the Haiku. Barthes understands the 'signs' of these Japanese social and cultural practices as operative in themselves, without requiring external referential sources to be considered truthful or authentic. For instance, Barthes argues that Japanese bowing inscribes politeness through culturally specific codes of practice, and does not suggest any sense of prostration. ${ }^{39}$ This is because the Japanese, in a general sense, do not see politeness or courtesy as hypocritical or something of which to be wary or suspicious. In contrast, Barthes states: 'Western man $[s i c]$ is reputed to be double, composed of a social, factitious, false "outside" and of a personal, authentic "inside" (the site of divine communication).'40 This means that, in the West, informal relations or casual ways of communicating are regarded as a reflection of the 'true' and 'authentic' self, whereas coded actions that signify politeness are considered 'artificial' and 'false'. The Japanese, however, see this apparent dichotomy between the inner self and the outer self differently. This division is commonly understood with the terms honne (inner feeling or personal view) and tatemae (presentation of the self as socially expected), a complementary pairing that is not dissimilar to the distinction between the 'back region' and the 'front region' of Erving Goffman's well-known dramaturgical analysis of everyday social performance. ${ }^{41}$ A Japanese individual is conscious of these two selves coexisting in oneself and in others in social situations. The Japanese are expected to alternate these two 'faces' according to circumstances.

The Japanese do not view the complementarity of two selves as oppositional because of the Japanese affinity with a social dynamic that has been discussed as a specifically Japanese dependency relation: amae. The Japanese term 'amae', meaning 
a desire for passive dependency, usually refers to the infant's dependency upon its mother, its unwillingness to leave the mother's protection. In his seminal study on Japanese society titled, The Anatomy of Dependency (originally published in 1971), psychiatrist and psychoanalyst Takeo Doi applies this infantile phenomenon to the larger Japanese society. ${ }^{42}$ In short, amae is used to discuss 'a need on the part of the Japanese individual to be passively loved, to be lovingly cared for (kawaigatte morau) by others' ${ }^{43}$ Relating amae to the Japanese sense of self, Doi explains that 'the Japanese divide their lives into inner and outer sectors each with its own, different, standards of behavior, no one feeling the slightest oddity in this discrepancy'. ${ }^{44}$ For example, rather than emphasising his individuality, a Japanese employee may identify himself or herself first as a company employee. Doi explains: 'If the rejection of the "small self" in favor of the "larger self" is extolled as a virtue, it becomes easier for him [sic] to act in concert with the group.'45 This construction thus indicates shared expectations that the company will look after the employee, and the employee can expect his or her efforts to be recognised and appreciated. This sense of amae provides guidance and support for individuals within communities, a social device that is said to have contributed to the economic success of Japan in the postwar era. As this example of the Japanese individual self defined by its attachment to a group may indicate, the Japanese self in the structure of amae is expressed not through the Western concept of the self as 'true' and 'authentic' but in terms of the mutual acts of amae between individuals in social situations.

At a personal level, amae demands that one imagine the other's possible actions in order to prepare one's own response. Japanese bowing, for example, can be understood as a sign of greeting as well as a signal for the other, and one's self, to perform the gesture. In a formal setting, especially between the elderly, such reciprocal gestural and vocal exchanges can continue for several rounds. Gestural protocols and customary verbal phrases are offered in precisely this manner in Japanese greeting rituals. I agree with Thomas Kasulis, a scholar of comparative religion and an expert on Japanese religion, that such acts of Japanese greeting are 'virtually conditioned reflexes'. ${ }^{46}$ In other words, as in Barthes's view, the salutation of Japanese bowing 'literally salutes no one' ${ }^{47}$ Of relevance to my argument here is the recognition that what is taking place is a communication through embodied codes. These embodied greeting practices are mutually spontaneous and yet deeply 
coded. Significantly, the approach to another's point of view in the Japanese amae formula can be extended to nonhuman objects. To explain this further, I will briefly discuss traditional ways of viewing the relationship among humans, nature and the environment in Japan in the following section, before examining cultural behaviors of the male otaku.

\section{— JAPANESE CONCEPTS OF INTERCONNECTEDNESS BETWEEN HUMANS AND OBJECTS}

It may not be immediately apparent, but I suggest that $k i$, a foundational concept, may also prepare the Japanese for relations with nonhuman agents, such as, where male otaku are concerned, cartoon characters. This concept is central to understanding how traditional Japanese beliefs, which still inform present-day social interaction, inflect not only Japanese mainstream behaviour, but also colour behaviours and beliefs within subcultures. In fact, $k i$ can already be used to describe one's feelings toward nonhumans. For example, someone might use the phrase ki ni naru (the ki becoming mindful of itself, that is, I am mentally preoccupied), when he or she describes their attention to a favourite gadget. The expression mirarete iru $k i$ ga suru (I have a sense of ki that suggests that I am being watched, that is, I feel being watched) can be used to describe the situation when you might sense that someone or something is behind you while you are sitting at a desk. These expressions reflect an awareness of the imagined point of view of the nonhuman thing. For example, a child may feel he or she is being watched by his or her toy, which might be a doll or a toy robot. To envision such relations with cartoon characters would be a contemporary extension of the Japanese traditional view of the fusion of humans with nature through $k i$-energy. ${ }^{48}$ Kasulis suggests that 'the lifeforce of $k i$ within the self's mind-body complex is also continuous with the life-force in the universe in its spirit-matter complex'.49 Similarly, Nagatomo discusses the interaction of ki-energy from 'the personal body' and that from 'an entity in the living ambiance'.50

At the same time, this interrelatedness with the nonhuman world is regarded as reflexively defining the self. In Buddhist thought, the human is defined by the nonhuman. Yuasa states that, in the Buddhist point of view, '[a] human being is a passive-active being which is made to live by nature'. ${ }^{51}$ The sense of the self in Buddhism is understood in relation to its surrounding environment. Importantly, 
bilateral relations with objects are conceived as embodied relations. ${ }^{52}$ Japanese philosopher Hiroshi Ichikawa states, in a manner that recalls Merleau-Ponty, that a skilful use of a tool means that the tool not only enters one's proprioceptive matrix, but one's perception is extended by the tool: 'dōgu ga mi ni tsuku' (a tool became part of $m i$ ). ${ }^{53}$ Unlike the physiological and biological body, the term $m i$ can be used to designate the living body as a much wider phenomenon that extends beyond the binary construction of body-and-mind. ${ }^{54}$ Ichikawa discusses his expanded notion of the body that includes potential extensions, not only through a mediation of tools and machines, but also through symbolic systems such as signs and language. 55 Once a person internalises signs or symbolic exchanges, they become part of the 'incarnated reality' of the person's living body: that is, mi no uchi ni naru (became inside $m i$ ). This understanding accords with that within traditional Japanese culture, as represented for example by the Zen garden or the figure of the onnagata in Kabuki (a male actor playing a female character), which embraces the artificial as a reality of the unreal. In these aesthetic traditions, the non-natural is celebrated because of its very artificiality: it is to do with a culturally established appreciation of the signs of aesthetic beauty.

From this perspective, the contemporary Japanese phenomenon of the otaku can be examined as an extended case of this highly culturally specific tradition of understanding signs in embodied terms that lie outside Western relations with the sign. The otaku provides a contemporary case study of this culturally specific embodied understanding as in the notions of $k i$ and $m i$, and the notion of performance in the formulae of amae.

\section{-EMBODIED SIGN AND SOCIAL PERFORMANCE}

Attempting to depathologise the otaku, psychiatrist and critic Tamaki Saitō, in his influential study Beautiful Fighting Girl, discusses the otaku's attraction to the characters of prepubescent super-heroines who fight against villains in manga and anime productions, such as Hayato Miyazaki's Kaze no Tani no Naushika (Nausicaä of the Valley of the Wind) (1982-1994) or Naoko Takeuchi's Sērā Mūn (Sailor Moon) (1992-1997). Saitō distinguishes these Japanese 'pure and lovable' girl warriors from the adult female superheroines of Western popular media, such as Xena in Xena: Warrior Princess (1995) or Lara Croft in Tomb Raider (1996), describing 
these figures as “'men in women's bodies" or female parodies of machismo'.56 For Saitō, the girl characters of the Japanese fictions are far more removed from physical reality than their Western counterparts. That is, according to Vincent, who is a cotranslator of the book and provides an introductory essay to it, such a character is 'a beautiful girl with no referent in reality' yet she is 'a fictional creature in her own right'. ${ }^{77}$ Saitō points out that, despite the unrealistic cartoon images of these girl characters, an otaku can gain actual sexual pleasure from images of these characters, whether they are two-dimensional or three-dimensional.58

Queer theories can be useful in examining otaku 'perversity'. For example, male otaku practice can be understood as antithetical to the hetero-normalcy of real bodies, which insists upon 'the self-evident [heterosexual] anatomical facticity of sex'.59 For Vincent, male otaku practice needs to be understood as sheer jouissance, 'an expression of an unrepressed and de-instrumentalized sexuality'.60 Though most of the male otaku are presumably heterosexual, their sexual engagement with images of fighting girls in manga and anime functions outside the biologically determined logic of sexuality. That is to say the otaku defies sexual norms, particularly the norm requiring that his desire 'must have an object in the real world (preferably of the opposite sex)'.61 Saitō's defense of otaku practice is exemplified by his remark that in the imaginary realm all human beings have the right to be perverts'.62 As Sedgwick similarly points out: 'Many people have their richest mental/emotional involvement with sexual acts that they don't do, or even don't want to do.'63 One's sexual fantasy and one's real life are two separate entities. Significantly, male otaku-who are, in fact, much more likely to be married men than solitary or criminal figures-are conscious of their actions of perceived perversity. ${ }^{64}$ It is in this sense that I suggest the utility of the concept 'queer' here, as the conscious occupying of a position at odds with 'normal' social roles that questions and indeed undermines its most basic assumptions about subjective identity and desire. An aspect of queering can be identified in the otaku's decoupling of sexual desire from 'social identities and naturalized bodies'.65

One must be cautious, however, as queer theories cannot be applied in an unqualified way to otaku practice. The otaku, for example, does not try to be a 'queer subject'. They are not intending to be political and critical, viewing queerness as revealing 'the inauthentic subject, living in conditions of forgery, unstable precisely 
because devoid of a stabilising core of "true being"', in the way Fabio Cleto defines the concept. ${ }^{66}$ Significantly, queer theories alone may not be adequate to examine the way that otaku simultaneously maintain both their actual heterosexuality and perverse, polymorphous fantasies without hierarchising them. While 'idolizing anime characters', the otaku are not 'making do with real women as substitutes in their everyday life'. ${ }^{67}$ According to Saitō, only their 'orientation of desire' is shifted.68

While Butler's notion of performativity may be an essential tool with which to discuss queer subversion, the same notion may have limited applicability in Japan for two reasons. First, the idea of the natural or the original as opposed to the unnatural or the copy is not necessarily perceived as oppositional, as I have discussed above; and second, otaku perversion does not express itself as irreducibly political and therefore subversive. I will briefly discuss Susan Sontag's notion of 'camp taste' and 'deliberate camp' to delineate similarities and differences in performative behaviour between the otaku and the camp subject.

Sontag, in her well-known essay 'Notes on Camp' (1964), discusses camp aestheticism alongside the notions of dandyism, connoisseurship and elitism in male gay culture before Stonewall. Camp culture functioned on the basis of the mobilising of hidden signs understood by insiders. For example, Sontag notes that camp 'taste' appreciates paradox, as in the phrase, 'it's good because it's awful'.69 This contradictory expression celebrates 'the good taste of bad taste' by finding 'the success in certain passionate failures'.70 Sontag also discusses the performative gestures of camp with the terms 'naïve' and 'deliberate'. 'Naive' camp is not conscious of its own vulgarity or kitschiness. 'Deliberate' camp consciously performs a kind of self-undermining through an outlandish and exaggerated manner, while turning its back 'on the good-bad axis of ordinary aesthetic judgment'.71 'Deliberate' camp finds aesthetic satisfaction in actions of 'naive' camp. Camp taste is very particular, and its exclusivity and inverse elitism can help create or define a community.

It is the question of 'taste' and exclusivity in relation to the insider knowledge particular to a 'subcultural' community that is relevant for my discussion of the otaku's particular sexual interest. Otaku culture appreciates the self-referential nature of comics, animation or games in relation to past works within a given genre. Otaku fans reflect expert knowledge in their areas of interest, as well as of 
traditional Japanese culture. For example, prominent Japanese commentators on the otaku, such as anime producer and essayist Toshio Okada, critic Eiji Otsuka and artist Takashi Murakami, talk about the connection between otaku culture and Japanese traditional thought and practices such as $i k i$ (the particular idea of chic or 'cool' in the Edo period), Kabuki, Bunraku, the paintings of Sansetsu Kanō and Shōhaku Soga and Buddhist sculpture. ${ }^{72}$ These claims regarding the otaku's strong link with Japanese traditional thought and aesthetic practices locate the otaku as a contemporary manifestation of cultural elitism. As for the particular sensibilities of camp aesthetics, the male otaku community exhibits specific, highly coded tastes about the consumption of fighting girl cartoon characters.

Referencing anthropologist Edward T. Hall, Saitō discusses manga and anime as 'high-context' media, meaning the messages communicated in these entertainment media are designed for insiders, fans who are already familiar with previous works of manga and anime..$^{73}$ Images valued by male otaku in the 1990s were not based on particular works or images by particular artists, but instead represented a synthesis of fragments and parts from what philosopher Hiroki Azuma calls the 'database' of this culturally specific imaginary, including manga, anime and SF films alongside more traditional, iconic images within Japanese visual culture. ${ }^{74}$ Some otaku are not only extremely informed fans of manga and anime, but produce new works by reinterpreting and appropriating their favourite manga and anime works, circulating these through dōjinshi (self-published magazines, manga and novels) and the internet.

However, these syntheses cannot be characterised by free association, because there are particular codes and styles through which the otaku feels 'moe', an intense excitement and desire that, in this context, drive otaku to consume these images. ${ }^{75}$ Part of the otaku's approach to images includes 'moe gijinka' (moe anthropomorphism), through which nonhuman entities (physical or virtual objects, commercial products, or even concepts) are anthropomorphised into beautiful young girls. The 'database', therefore, can be understood as a contemporary Japanese 'habitus' for otaku culture, to use Bourdieu's term. The otaku's sexual fantasies are therefore grounded in this highly coded, subcultural habitus. Male otaku are channelled to feel sexual arousal when they see, for example, a 'cute' manga girl with cat-like ears, dressed in a maid's costume. Saitō regards moe 
anthropomorphism as a contemporary exercise of mitate, a techniques often used in traditional arts forms such as ukiyo-e, in which cultures of high and low art are juxtaposed to generate layering of meaning, often for a humorous effect.76 Male otaku respond to accepted codes of sexiness within their in-group, formed through dojjinshi and the internet sites. Azuma argues that the way the 1990s otaku consumed these images was 'animal-like' (or like 'drug addicts'), that is, following immediate biological needs rather than in relation to 'human desire', as such.77 Elaborating on Azuma's 'behaviorist diagnosis', Japanese studies scholar Thomas Lamarre describes the moe action as 'an automatic behavioral response'.78

I will now connect the otaku's sexual 'behaviourism' in response to such images with my earlier discussion on social response in Japanese culture and the role of signs. What male otaku respond to are in fact metonymical signs of sexiness. In other words, the otaku care about ideas of sexiness, without laying much emphasis upon their substance. As Vincent argues, the otaku's attachment to the image counters 'those who insist that desire must be rooted in real bodies'. ${ }^{79}$ Manga critic Gō Itō's notion of kyara (proto-character) articulates the metonymical effects in the otaku practice. ${ }^{80}$ In examining the history of Japanese manga, Itō distinguishes Japanese manga characters (kyarakutā) from the ones of kyara. For Itō, the formers are described and regarded as human-like, with personalities, and their stories reflect life and living. A kyara, on the other hand, is much more simply drawn, and is often caricature-like. Yet, for serious manga fans, a popular kyara can offer a certain presence in itself, without being imbedded within a manga story. For Itō, moe can mean a response to the intensity of a kyara.81 It is along these lines that Saitō discusses otaku icons as kyara, and their sexual fantasies concerning them, as kyara moe. ${ }^{82}$ Male otaku are, then, responding to ideas of the erotic that are metonymically generated through these images.

The notion of kyara could be extended to anything, as long as it can become essentialised through processes of popularisation, narrativisation, idealisation or fictionalisation. Indeed, otaku themselves can become kyara. Interestingly, Saitō applies the notion of kyara to the wider Japanese society. Kyara in this context refers to recognisable roles and stereotypes in social and communicative situations in the wider Japanese culture. For example, baka-kyara means the role of the fool. Majimekyara means the role of a serious and honest person. Similarly to Barthes's analysis 
of social signs, Saitō argues that the Japanese see playing the right role in a given social situation more important than being 'true' to oneself. ${ }^{83}$ In describing themselves in terms of the roles that they are required to play, the Japanese expect others to understand they are playing the role, and therefore, in accord with the notion of amae, that the community accepts and protects him or her.

Crucially, the otaku's highly coded anthropomorphism of the image means that the image is understood to be giving something back in an imagined circuit of reciprocity. Kyara moe requires the 'presence' of the other, in a way not dissimilar to traditional Japanese intersubjective social behaviours. For example, while male otaku visually consume images of young girls, these figures seem to look back at the otaku with their large cartoon eyes, and the otaku feels he is being watched. ${ }^{84}$ The girl figure's imagined gaze at the otaku grants the image an 'aliveness'. Even Saitō states that he feels he is being watched by the author of female cartoon characters when perusing these girl-images. ${ }^{85}$ As for traditional Japanese anthropomorphism, moe anthropomorphism is reflexive.

This reflexivity is an important aspect of otaku in-group behaviour. That is to say, the otaku's excitement about these images of girls is moderated as a performance or the pretence of enthusiasm as a 'cool' gesture toward the other otaku, who might be more seriously invested in these images, or to the non-otaku community who might hold a negative view of otaku. Azuma discusses the otaku's logic as the double operation of a voyeur who follows the 'norm' of the otaku aesthetic and is also the self-observing voyeur. ${ }^{86}$

Paradoxically, although the figure of the otaku has become more acceptable to mainstream Japanese culture, the otaku's consumption of images of the cute fighting girl has been criticised in relation to pedophilia, sadism, masochism and fetishism. ${ }^{87}$ According to Saito the otaku, rather than rejecting these labels, find in them an 'alibi' for their perceived perversity. ${ }^{88}$ That is, the otaku are 'performing' an otaku kyara who is regarded as a 'dame' (useless or hopeless) person who cannot resist his 'pathetic' attraction to the cartoon images of young girls. ${ }^{89}$ The label of otaku works metonymically, as a separate entity, to protect the person who wears it. At the same, functioning like an avatar in games, the otaku label allows a person declaring himself to be an otaku to experience something 'real' when consuming the young girl image in manga, anime and games. 
In the same vein, the otaku's kyara moe creates another buffer. As we discussed above, stock figures, or kyara, are generated from a vocabulary of these, a 'database'. As Azuma points out, the database is constituted on the basis of collective decisions made by the otaku community regarding what is 'real' for them..$^{90}$ This means that the otaku is following certain unspoken rules or codes regarding kyara. The message is that if you are an otaku, you should feel moe toward kyara. The duality of the relation of the performing self to the sign lies at the heart of the otaku gesture: an otaku is conscious of performing being an otaku, while simultaneously being an audience within the otaku community-while experiencing a 'real' somatic responsiveness toward objects of carnal affection. The otaku can present this performed self in an infinite loop of 'performing' and 'performed'.

The otaku's self-reflexive gesture through the guise of self-undermining and self-parody within the otaku community and in the context of Japanese society suggests that the 'true' self is suspended, not self-assertively-as in 'deliberate camp'-but as a contemporary expression of an iterative and undecidable relation between the Japanese self and sign. Unlike the otaku subject, the queer subject is understood as irreducible, the agent of performance, with the capacity to perform conscious acts of 'deliberate camp'. Deliberate camp is queer because it renders his subjective position, unquestioned in mainstream, normative culture, as in flux.

According to Cleto, the camp subject is 'objectified into a prop, a piece of theatrical furniture, a pure mask'. ${ }^{91}$ The camp subject as an actor is only actualised through performing roles that correspond to the camp person's identity. That is, personality becomes equal to the mask as paradoxical essence, or depthless foundation of subjectivity as actor (in itself, non-existent without an audience) on the world as stage'.92 Yet, these two antithetical modes of existence-authenticity and theatricality-coexist in the camp act, which embraces contradiction. Arguing 'camp is queer as a mode of being', Cleto articulates that '[i]ntentions, seriousness and their correlates (politics and agency) are there, and yet they are only present in a queer articulation'. ${ }^{93}$ In other words, the 'deliberate camp' subject is conducting what performance theorist Richard Schechner called 'showing doing', not on stage, but in the realm of the everyday. ${ }^{94}$ That is, he is aware of his own performance as a dual operation, playing the roles of actor and audience. Just as in theatrical role-play, the camp subject is suspended between 'not me' and 'not not me'. ${ }^{95}$ Importantly, the 
queerness of camp subjectivity lies in its self-declaration, which is expressed overtly and aggressively both to one's own community and to the public. In contrast, otaku subjectivity is expressed through the form of a performed self that is a 'shield' protecting his secret acts of 'perverse' desire. At the core of the otaku practice, it is the Japanese culture of performance that establishes a performing self that can have embodied relations with signs. The otaku practice is a particular manifestation of Japanese traditions of intersubjectivity in the age of the internet. The actual 'perversity' of otaku practice lies in the fact that accepted and unquestioned Japanese traditions of social performance and embodiment provide its core structure, operating in conjunction with forms that technology has given rise to, moderated by contemporary social and cultural expectations.

\section{-CONCLUSION}

The otaku has developed a highly specific cultural literacy that adapts traditional concepts of bodily relations to the nonhuman world in terms of its own aims. For example, the otaku's negation of the distinction between 'the artificial' and 'the real' in his attachment to particular images can be seen as a contemporary, subcultural version of what one might call the realim of the non-real that is exemplified by Kabuki and the Zen garden. The male otaku's focusing of sexual desire upon images of the cute fighting girl parallels the situation of the viewer of a Zen garden who can appreciate the essence of nature in the artificially constructed, enclosed garden environment. Within the social 'behaviourism' of the otaku subculture, the male otaku participates in its collective 'sense-making rituals' around the fighting girl characters that are the objects of sexual desire, and the otaku understands them somatically: through 'habits' of sensing and a sexualised response. The theatricalised and contained context for otaku culture, seen in terms of the reciprocity of the wider, culturally accepted phenomenon of amae, permits the otaku's actions and tastes, even if this subculture is seen as (partly) outside the mainstream. Importantly, it operates on the basis of reflexive social behaviours and structures of self-definition that shape mainstream culture. The concept of kyara gives otaku a kind of agency-like an 'avatar' in a game-to engage sexually with fighting girl cartoon images. 
The Japanese tradition of embodied intersubjective (and intercategorical) relations, articulated through the notions of ' $k i$ ' and ' $m i$ ', present potent preconditions for the otaku's somatic attachments to these images. The traditional thinking about the self as relational is embedded in common terms and concepts such as $k i$ that point to connections among the self, objects and environment. These connections are understood by Japanese people more broadly in deeply somatic terms that can be complex and flexibly applied, as Ichikawa's discussion of ' $m i$ ' indicates. What should be highlighted is the observation that Japan remains a 'highcontext' society, even in the twenty-first century, and even after over a century of contact with Western modes of communication and cultural forms. There are implicit expectations among the Japanese people that take form as commonly shared social tropes, iconic concepts and other symbolic constructs. They can function both synchronically and diachronically for their audience (the insiders, the Japanese) who share highly specific knowledge about these terms and concepts. The result is a fundamentally embodied relation to the world, including its nonhuman elements, precisely through such symbolic constructs. Importantly, the behaviour of subcultures in Japan can also be fundamentally shaped by this relation. The otaku do not subvert or undermine it, but instead incorporate and elaborate upon it. The situation of the otaku provides a unique contemporary case study concerning the bodily relation to signs that Japanese culture facilitates, revealing a new twentyfirst-century facet of Barthes's understanding of Japan as an 'empire of signs'.

Yuji Sone is a lecturer and performance researcher at Macquarie University. His research focuses on the cross-disciplinary conditions of mediated and technologised performance and the terms that may be appropriate for analysing such work, especially in relation to Japanese social and cultural frameworks concerning intersubjectivity and embodiment. 


\section{-ACKNOWLEDGEMENTS}

I would like to thank Professor Joseph Pugliese for constructive comments that have greatly assisted the development of this article.

\section{-NOTES}

1 Aki Enomoto, Otaku no koto ga omosiroi hodo wakaru hon [An Easy Guide to Otaku], Chūkei shuppan, Tokyo, 2009. Japanese names are written here in the English way: given name first, followed by family name. Long vowel sounds are indicated by diacritical marks, unless in common usage in Romanised form (for example, Tokyo, not Tōkyō).

2 Alongside male otaku culture, there is also a type of female nerd (fujoshi) with its own subculture, called yaoi. For a discussion on yaoi sexuality, see Tamaki Saitō, 'Otaku Sexuality', in Robot Ghosts, Wired Dreams: Japanese Science Fiction from Origins to Anime, eds. Christopher Bolton, Istvan CsicseryRonay Jr, and Takayuki Tatsumi, University of Minnesota Press, Minneapolis and London, 2007, pp. 222-49; Patrick W. Galbraith, 'Fujoshi: Fantasy Play and Transgressive Intimacy among "Rotten Girls” in Contemporary Japan', Signs: Journal of Women in Culture and Society, vol. 37, no. 1, 2011, pp. 211-32. 3 Yoshimasa Kijima, 'The Fighting Gamer Otaku Community: What Are They “Fighting” About?' in Fandom Unbound: Otaku Culture in a Connected World, eds Mizuko Ito, Daisuke Okabe and Izumi Tsuji, Yale University Press, New Haven and London, 2012, pp. 249-74.

4 Thiam Huat Kam, "The Anxieties that Make the "Otaku": Capital and the Common Sense of Consumption in Contemporary Japan', Japanese Studies, vol. 33, no. 1, 2013, pp. 39-61. The term was received extremely negatively in the late 1980s when Tsutomu Miyazaki, a pedophile serial killer, was described in the public domain as an otaku.

5 Carolyn Stevens, 'You Are What You Buy: Postmodern Consumption and Fandom of Japanese Popular Culture', Japanese Studies, vol. 30, no. 2, 2010, p. 212.

${ }^{6}$ Koichi Iwabuchi, “'Soft” Nationalism and Narcissism: Japanese Popular Culture goes Global', Asian Studies Review, vol. 26, no. 4, 2002, pp. 447-69. Iwabuchi observes the rise of cultural essentialist discourses in Japan in the 1990s in relation to Japan's cultural exports in the global markets.

7 Mizuko Ito, 'Introduction', in Ito et al., Fandom Unbound, p. xii.

8 Shiji Miyadai, Otakuteki soōzōryoku no rimitto (The Limit of Otaku Imagination), Chikuma shobō, Tokyo, 2014, p. 18.

${ }^{9}$ David Morley and Kevin Robins, Space of Identity: Global Media, Electronic Landscapes and Cultural Boundaries, Routledge, London, 1995, pp. 147-73.

10 Lucy Suchman, Human-Machine Reconfigurations: Plans and Situated Actions, Cambridge University Press, New York, 2007, p. 7.

${ }^{11}$ Anne Allison, Millennial Monsters: Japanese Toys and the Global Imagination, University of California Press, Berkeley and Los Angeles, 2006, p. 13. 
12 Ibid., p. 85.

${ }^{13}$ Casper Bruun Jensen and Anders Blok, 'Techno-animism in Japan: Shinto Cosmograms, Actornetwork Theory, and the Enabling Powers of Non-human Agencies', Theory, Culture \& Society, vol. 30, no. 2, 2013, p. 84. I take the view that the relationship between nature and culture within Japanese techno-animism remains an asymmetric one, leaning toward culture. This becomes evident in an examination of the otaku's sociomaterial engagement.

14 Patrick Galbraith, 'Bishōjo Games: “Techno-Intimacy” and the Virtually Human in Japan', The International Journal of Computer Game Research, vol. 11, no. 2, 2011, np, <http://gamestudies.org/1102/articles/galbraith>.

15 Judith Butler had famously developed, in her earlier work, her discussion of gender performativity by applying to gender Victor Turner's view of the repetitive performance of ritual social drama as both reenactment and re-experiencing. Judith Butler, 'Performative Acts and Gender Constitution: An Essay on Phenomenology and Feminist Theory', Theatre Journal, vol. 40, no. 4, 1988, pp. 519-31.

16 Susan Sontag quoted in Moe Meyer, The Politics and Poetics of Camp, Routledge, London and New York, 1994, p. 117.

${ }^{17}$ Fabio Cleto, Camp: Queer Aesthetics and The Performing Subject, Edinburgh University Press, Edinburgh, 1999, pp. 16-17.

18 Ibid., p. 30, original emphasis. Robert Reynolds, on the other hand, uses the terms 'camp' and 'queer' to discuss generational differences in defining gay and lesbian life in Australia. Robert Reynolds, From Camp to Queer: Re-making the Australian Homosexual, Melbourne University Press, Melbourne, 2002. 19 David M. Halperin, How To Be Gay, Belknap Press of Harvard University Press, Cambridge, MA, 2012, pp. 490-1, n1.

${ }^{20} \mathrm{~J}$. Keith Vincent, translator's introduction, 'Making It Real: Fiction, Desire, and the Queerness of the Beautiful Fighting Girl', in Tamaki Saitō, Beautiful Fighting Girl, trans J. Keith Vincent and Dawn Lawson, University of Minnesota Press, Minneapolis, 2011, p. xviii.

21 Ibid., pp. xviii-xxii.

${ }^{22}$ For discussions on LGBT issues in Japan, see Mark McLelland, Katsuhiko Sugawara and James Welker, Queer Voices from Japan: First-Person Narratives from Japan's Sexual Minorities, Lexington Books, Lanham, MD, 2007. McLelland et al. point out that same-sex relationships were socially accepted and were termed nanshoku (male eroticism) in the pre-modern Edo period. Only after European sexology was introduced in the Meiji period of modernisation in the late nineteenth century was nanshoku discussed in relation to imported concepts such as 'perverse' or 'queer' (Ibid., pp. 6-7). 23 The Japanese word hentai has been used in the porn industry in English-speaking countries for Japanese pornographic comics, animation and games. Video game theorist Ian Bogost discusses the very violent, disturbing and misogynistic nature of these Japanese porn products as a lesson in 'the various logics of perversion that stimulate other human beings'. Ian Bogost, How to Do Things with Videogames, University of Minnesota Press, Minneapolis, 2011, p. 109. 
24 Emiko Ohnuki-Tierney, The Monkey as Mirror: Symbolic Transformations in Japanese History and Ritual, Princeton University Press, Princeton, 1987.

25 Phillip Vannini, Dennis Waskul and Simon Gottschalk, The Senses in Self, Society, and Culture: A Sociology of the Senses, Routledge, New York, 2012, p. 86.

${ }^{26}$ Herbert Blumer, George Herbert Mead and Human Conduct, ed. Thomas J. Morrione, AltaMira Press, Walnut Creek, CA, 2004, p. 90.

27 Ibid.

${ }^{28}$ Vannini et al., p. 86.

${ }^{29}$ Ibid.

30 Ibid., p. 87.

31 Ibid., pp. 87-8.

32 Hisa A. Kumagai, 'Ki: The "Fervor of Vitality” and the Subjective Self', Symbolic Interaction, vol. 11, no. 2,1988 , p. 184. In a manner similar to Mead's concept of the 'Me' and the 'I', Kumagai defines jibun, the Japanese sense of the self, as 'a composite of "the notion" of self ([as] cognitively constructed) and "the sense" of self ([as] subjectively experienced)'. Ibid.

33 Yasuo Yuasa, The Body, Self-Cultivation, and Ki-Energy, trans. Shigenori Nagatomo and Monte S. Hull, State University of New York Press, Albany, 1993, p. 108.

34 Shigenori Nagatomo, 'Ki-Energy: Underpinning Religion and Ethics', in Merleau-Ponty and Buddhism, eds Jin Y. Park and Gereon Kopf, Lexington Books, Langham, MD, 2009, p. 234.

35 Ibid.

36 Edward T. Hall, Beyond Culture, Anchor Books, New York, 1989, p. 113. Hall remarks that, in a 'highcontext' culture, messages are often conveyed in what is unsaid, which serves the members of an ingroup who share common expectations and who have had similar experiences.

${ }^{37}$ Satoshi Hamano, Āki tekuchā no seitaikē (The Ecology of Architecture): jōhō kankyō wa iakani sekkei saretakitaka, Tokyo, NTT Shuppan, 2008, pp. 105-16.

${ }^{38}$ Roland Barthes, Empire of Signs, trans. Richard Howard, Jonathan Cape, London, 1983.

${ }^{39}$ Ibid., pp. 63-8.

40 Ibid., p. 63.

${ }^{41}$ Erving Goffman, The Presentation of Everyday Life, Anchor Books, New York, 1959, p. 123.

42 Takeo Doi, The Anatomy of Dependence, trans John Bester, Kōdansha International, Tokyo, 2001.

${ }^{43}$ Hisa A. Kumagai, and Arno K. Kumagai, "The Hidden "I" in Amae: "Passive Love" and Japanese Social Perception', Ethos, vol. 14, no. 3, 1986, p. 307.

${ }^{44}$ Doi, pp. 42-3.

45 Ibid., p. 135. 
46 Thomas Kasulis, 'The Body: Japanese Style' in Self as Body in Asian Theory and Practice, eds Thomas P. Kasulis with Roger T. Ames and Wimal Dissanayake, State University of New York Press, Albany, 1993, p. 318.

47 Barthes, p. 68.

${ }^{48}$ An indigenous concept of mono no aware (literally, 'the pathos of things', meaning a sensitivity to ephemera) can be discussed as another concept that facilitates the fusion of organic and non-organic.

${ }^{49}$ Kasulis, p. 308.

50 Shigenori Nagatomo, Attunement Through The Body, State University of New York Press, Albany, 1992, p. 198.

51 Yuasa, p. 109.

52 These notions foster the embodied interrelation that becomes central to the conception of shutai, which is equivalent to 'the subject' in English, but incarnated. In other words, the subject is intermixed with the external physical world, forming shutai as an embodied whole, a kind of 'sensuous self'. 53 Hiroshi Ichikawa, Mi no Kōzō (The Structure of the Body), Kōdansha, Tokyo, 1993, p. 202.

${ }^{54}$ Ichikawa identifies fourteen related meanings of mi: fruit of a plant, dead flesh, living flesh, a whole body, one's figure, costume on the body, life, social existence, a singular self, selves, social self, social status, and mental, incarnate and spiritual existence. Ibid., pp. 80-3.

55 Hiroshi Ichikawa, Seishin tositeno Shintai (The Body as Spirit), Kōdansha, Tokyo, 1992, p. 265.

56 Saitō, Beautiful Fighting Girl, p. 7.

57 Vincent, pp. $\mathrm{x}$-xi.

58 Saitō, Beautiful Fighting Girl, pp. 30, 37.

${ }^{59}$ Butler cited in Vincent, p. xxi. I should point out that while I discuss traditional forms of Japanese culture that predate contact with the West, in this article I consider Japanese subjectivity in the wake of Western modernity. Vincent, for example, deploys an understanding of the male heterosexual norm of Western modernity to the Japanese context.

60 Vincent, p. xviii.

61 Ibid., xviii.

62 Saitō, Beautiful Fighting Girl, p. 31.

63 Elisabeth Kosofsky Sedgwick, Epistemology of The Closet, University of California Press, Berkeley and Los Angels, 1990, p. 25.

64 Saitō, Beautiful Fighting Girl, p. 30.

65 Vincent, p. xx.

66 Cleto, p. 13.

${ }^{67}$ Saitō, p. 30.

68 Ibid.

${ }^{69}$ Susan Sontag, 'Notes on “Camp"', quoted in Cleto, p. 65. 
70 Ibid.

71 Ibid., p. 61.

72 Hiroki Azuma, Dōbutsuka suru posuto modan (The Animalizing Postmodern), Kōdansha, Tokyo, 2001, pp. 16-8.

73 Tamaki Saitō, Kyarakutā seishin bunseki (Character Psychoanalysis), Chikuma shobō, Tokyo, 2011, pp. 155-6.

${ }^{74}$ Azuma, p. 52.

75 Ibid., pp. 66-70.

76 Saitō, Kyarakutā seishin bunseki, p. 179.

${ }^{77}$ Azuma, pp. 126-9.

78 Thomas Lamarre, The Anime Machine: A Media Theory of Animation, University of Minnesota Press, Minneapolis, MN, 2009, p. 259.

${ }^{79}$ Vincent, p. xxii.

80 Gō Itō, Tezuka izu deddo (Tezuka is Dead), NTT Shuppan, Tokyo, 2005.

81 Ibid., 104.

${ }^{82}$ Saitō, Kyarakutā seishin bunseki, p. 142.

83 Ibid., pp. 231-2.

84 Ibid., p. 220.

85 Ibid.

${ }^{86}$ Azuma, p. 100.

87 Vincent discusses the polarisation in academic debates over the fighting girls between the feminist interpretation ('a welcome sign of empowerment') and the 'sexist' one ('hypersexualized and borderline pedophile image'), Vincent, pp. ix-x. In my view, these girl images are neither radical nor political in the sense of subversiveness or resistance to social norms. I agree with Lamarre's point that the homosociality of otaku culture as a 'heterosexual therapy for the computer age' maintains heterosexual normativity; see Lamarre, p. 257. However, Japanese heterosexual normativity may not be monolithic, and clearly can accommodate otaku activities situated between 'the otaku's actual heterosexual "wholesomeness" and the polymorphous perversity of their fantasies'; Vincent, p. xx. ${ }^{88}$ Saitō, Beautiful Fighting Girl, p. 31.

${ }^{89}$ Hiroki Azuma, Gēmuteki riarizume no tanjō (The Birth of Game-like Realism), Kōdansha gendai shinsho, Tokyo, 2007, p. 316.

${ }^{90}$ Azuma, Gēmuteki riarizume no tanjō, pp. 60-1.

91 Cleto, p. 25.

92 Ibid.

93 Ibid., pp. 29, 30. 
94 Richard Schechner, Performance Studies: An Introduction, Routledge, London and New York, 2006, p. 28.

95 Richard Schechner, Between Theater and Anthropology, University of Pennsylvania Press,

Philadelphia, 1985, p. 112.

\section{-BIBLIOGRAPHY}

Allison, A., Millennial Monsters: Japanese Toys and the Global Imagination, University of California Press, Berkeley and Los Angeles, 2006.

Azuma, H., Dōbutsuka suru posuto modan (The Animalizing Postmodern), Kōdansha, Tokyo, 2001.

Azuma, H., Gēmuteki riarizume no tanjō (The Birth of Game-like Realism), Kōdansha gendai shinsho, Tokyo, 2007.

Barthes, R., Empire of Signs, trans. Richard Howard, Jonathan Cape, London, 1983.

Blumer, H., George Herbert Mead and Human Conduct, ed. Thomas J. Morrione, AltaMira Press, Walnut Creek, CA, 2004.

Bogost, I., How to Do Things with Videogames, University of Minnesota Press, Minneapolis, 2011.

Butler, J., 'Performative Acts and Gender Constitution: An Essay on Phenomenology and Feminist Theory', Theatre Journal, vol. 40, no. 4, 1988. doi: http://dx.doi.org/10.2307/3207893

Cleto, F., Camp: Queer Aesthetics and The Performing Subject, Edinburgh University Press, Edinburgh, 1999.

Doi, T., The Anatomy of Dependence, trans John Bester, Kōdansha International, Tokyo, 2001.

Enomoto, A., Otaku no koto ga omosiroi hodo wakaru hon [An Easy Guide to Otaku], Chūkei shuppan, Tokyo, 2009.

Galbraith, P.W., 'Bishōjo Games: “Techno-Intimacy” and the Virtually Human in Japan', The International Journal of Computer Game Research, vol. 11, no. 2, 2011, http://gamestudies.org/1102/articles/galbraith.

Galbraith, P. W., 'Fujoshi: Fantasy Play and Transgressive Intimacy among "Rotten Girls" in Contemporary Japan', Signs: Journal of Women in Culture and Society, vol. 37, no. 1, 2011. doi: http://dx.doi.org/10.1086/660182

Goffman, E., The Presentation of Everyday Life, Anchor Books, New York, 1959.

Hall, E. T., Beyond Culture, Anchor Books, New York, 1989.

Halperin, D. M., How To Be Gay, Belknap Press of Harvard University Press, Cambridge, MA, 2012. doi: http://dx.doi.org/10.4159/harvard.9780674067516

Hamano, S., Āki tekuchā no seitaikē (The Ecology of Architecture): jōhō kankyō wa iakani sekkei saretakitaka, Tokyo, NTT Shuppan, 2008.

Ichikawa, H., Seishin tositeno Shintai (The Body as Spirit), Kōdansha, Tokyo, 1992.

Ichikawa, H., Mi no Kōzō (The Structure of the Body), Kōdansha, Tokyo, 1993. 
Iwabuchi, K., 'Soft' Nationalism and Narcissism: Japanese Popular Culture goes Global', Asian Studies Review, vol. 26, no. 4, 2002. doi: http://dx.doi.org/10.1080/10357820208713357

Jensen, C. B. and A. Blok, 'Techno-animism in Japan: Shinto Cosmograms, Actor-network Theory, and the Enabling Powers of Non-human Agencies', Theory, Culture \& Society, vol. 30, no. 2, 2013. doi: http://dx.doi.org/10.1177/0263276412456564

Itō, G., Tezuka izu deddo (Tezuka is Dead), NTT Shuppan, Tokyo, 2005.

Kam, T. H., "The Anxieties that Make the "Otaku": Capital and the Common Sense of Consumption in Contemporary Japan', Japanese Studies, vol. 33, no. 1, 2013. doi: http://dx.doi.org/10.1080/10371397.2013.768336

Kasulis, T., 'The Body: Japanese Style' in Self as Body in Asian Theory and Practice, eds Thomas P. Kasulis with Roger T. Ames and Wimal Dissanayake, State University of New York Press, Albany, 1993.

Kijima, Y., 'The Fighting Gamer Otaku Community: What Are They "Fighting” About?' in Fandom Unbound: Otaku Culture in a Connected World, eds Mizuko Ito, Daisuke Okabe and Izumi Tsuji, Yale University Press, New Haven and London, 2012.

Kumagai, H. A. and A. K. Kumagai, "The Hidden "I" in Amae: "Passive Love" and Japanese Social Perception', Ethos, vol. 14, no. 3, 1986. doi: http://dx.doi.org/10.1525/eth.1986.14.3.02a00040

Kumagai, H. A., 'Ki: The "Fervor of Vitality" and The Subjective Self', Symbolic Interaction, vol. 11, no. 2, 1988. doi: http://dx.doi.org/10.1525/si.1988.11.2.175

Lamarre, T., The Anime Machine: A Media Theory of Animation, The University of Minnesota Press, Minneapolis, MN, 2009.

McLelland, M., K. Sugawara and J. Welker, Queer Voices from Japan: First-Person Narratives from Japan's Sexual Minorities, Lexington Books, Lanham, MD, 2007.

Meyer, M., The Politics and Poetics of Camp, Routledge, London and New York, 1994.

Miyadai, S., Otakuteki soōzōryoku no rimitto (The Limit of Otaku Imagination), Chikuma shobō, Tokyo, 2014.

Morley, D. and K. Robins, Space of Identity: Global Media, Electronic Landscapes and Cultural Boundaries, Routledge, London, 1995. doi: http://dx.doi.org/10.4324/9780203422977

Nagatomo, S., Attunement Through The Body, State University of New York Press, Albany, 1992.

Nagatomo, S., 'Ki-Energy: Underpinning Religion and Ethics' in Merleau-Ponty and Buddhism, eds Jin Y. Park and Gereon Kopf, Lexington Books, Langham, MD, 2009.

Ohnuki-Tierney, E., The Monkey as Mirror: Symbolic Transformations in Japanese History and Ritual, Princeton University Press, Princeton, 1987.

Reynolds, R., From Camp to Queer: Re-making the Australian Homosexual, Melbourne University Press, Melbourne, 2002. 
Saitō, T.,'Otaku Sexuality', in Robot Ghosts, Wired Dreams: Japanese Science Fiction from Origins to Anime, eds. Christopher Bolton, Istvan Csicsery-Ronay Jr., and Takayuki Tatsumi, The University of Minnesota Press, Minneapolis and London, 2007.

Saitō, T., Kyarakutā seishin bunseki (Character Psychoanalysis), Chikuma shobō, Tokyo, 2011.

Schechner, R., Between Theater and Anthropology, University of Pennsylvania Press, Philadelphia, 1985.

Schechner, R., Performance Studies: An Introduction, Routledge, London and New York, 2006.

Sedgwick, K., Epistemology of The Closet, University of California Press, Berkeley and Los Angels, 1990.

Stevens, C., 'You Are What You Buy: Postmodern Consumption and Fandom of Japanese Popular Culture', Japanese Studies, vol. 30, no. 2, 2010. doi: http://dx.doi.org/10.1080/10371397.2010.497578

Suchman, L., Human-Machine Reconfigurations: Plans and Situated Actions, Cambridge University Press, New York, 2007.

Vannini, P., D. 'Waskul and S. Gottschalk, The Senses in Self, Society, and Culture: A Sociology of the Senses, Routledge, New York, 2012.

Vincent, J. K., Making It Real: Fiction, Desire, and the Queerness of the Beautiful Fighting Girl', in Tamaki Saitō, Beautiful Fighting Girl, trans J. Keith Vincent and Dawn Lawson, University of Minnesota Press, Minneapolis, 2011.

Yuasa, Y., The Body, Self-Cultivation, and Ki-Energy, trans. Shigenori Nagatomo and Monte S. Hull, State University of New York Press, Albany, 1993. 